\title{
Empowerment of Islamic Communities through Agribusiness Efforts to Improve the Economic Welfare of the Pekalongan Community in East Lampung Regency
}

\author{
Bayu Prafitri ${ }^{1}$, Khomsahrial Romli ${ }^{2}$, Hasan Mukmin $^{3}$, Fitri Yanti ${ }^{4}$ \\ \{bayuprafitri2104@gmail.com ${ }^{1}$,khomsahrial@gmail.com², hasanmukmin@radenintan.ac.id ${ }^{3}$, \\ fitriyanti@radenintan.ac.id $\left.{ }^{4}\right\}$ \\ Universitas Islam Negeri Raden Intan Lampung, Bandar Lampung, Indonesia ${ }^{1}$, Universitas Islam \\ Negeri Raden Intan Lampung, Bandar Lampung, Indonesia ${ }^{2}$, Universitas Islam Negeri Raden Intan \\ Lampung, Bandar Lampung, Indonesia ${ }^{3}$, Universitas Islam Negeri Raden Intan Lampung, Bandar \\ Lampung, Indonesia ${ }^{4}$
}

\begin{abstract}
The development of an Islamic community in the form of empowerment is a way in which society is able to move and act to change a condition through the development of agribusiness in Pekalongan, East Lampung as a form of Islamic Business in increasing competitiveness through comparative advantage, contributing, and job opportunities as well as a significant source of income for the community through agribusiness in increasing the economic income of the people of Pekalongan District, East Lampug Regency. Community development in empowerment is an effort to improve the community's economy and in accordance with the social values of the community. This research is a field research (field research) with a descriptive approach. The instruments used were interview guidelines and observation guidelines. The data analysis techniques used were data reduction, presenting data and drawing conclusions and verification. The results of this study indicate that the empowerment of the Islamic community in improving the community economy in Pekalongan, East Lampung 1) Developing agribusiness technology, 2), building cooperation, empowerment carried out in accordance with Islamic Business which is designed to put more emphasis on the efforts of economic empowerment of the Ummah.
\end{abstract}

Keywords: Islamic Community Empowerment, Technology Agribusiness.

\section{Introduction}

Community development in the form of empowerment is a way of how society is able to move and act to change an existing condition for the better and more empowered.[1] Meanwhile, one of the keywords at this time that is often echoed by all levels of society is the word increase in human resources. This word has a more specific meaning regarding how to improve the condition of the existing society for the better in the future.

Community development in the desired empowerment process is to be able to develop the ability of individuals or social groups from weak or less empowered communities to become independent communities that have the ability to be able to develop them optimally and have an impact on increasing the community's economy, so that people who are less capable and less developed as well as people who do not have a job must be empowered according to their 
abilities, as an effort to improve the economic welfare of people who are based on agribusiness, including the following:

a. Economic improvement, especially food sufficiency

b. Increased welfare

c. Freedom and guaranteed security [2].

The importance of development with an agribusiness approach is due to several reasons, namely: increasing competitiveness through comparative advantage, it is the main regional economic sector that contributes, and employment opportunities and is a significant new source of growth.

Utilizing the potential of the area in Pekalongan, East Lampung with quite prospective opportunities, which is through community empowerment through agribusiness, which is a series of agricultural potential activities as a tourist attraction, both potential in the form of natural landscapes, agricultural areas, as well as the uniqueness and diversity of production activities and agricultural technology. as well as the culture of the farming community and have an impact on increasing community income which is one of the biggest centers of agribusiness in Indonesia.

Based on the description of the background of the problem above, problems can be identified by looking at the development of agribusiness businesses that have been running to date, but there are still many youths of productive age and some people who do not work or are unemployed in Pekalongan, East Lampung.

From the background and some of the problem identification above, the researcher focuses on this dissertation on the Islamic Community Empowerment Strategy through Horticultural Plant Business and Its Implications for Community Economic Welfare in Pekalongan District, East Lampung Regency.

Based on the identification and focus of the above problems, the authors formulate the problem is How to Empower Islamic Communities through Agribusiness Efforts in improving the economic welfare of the community in Pekalongan District, East Lampung Regency

\section{Theoretical Framework}

Community development in the form of empowerment is a way and an effort of how society is able to move and act to change an existing condition to be better and more empowered and able to develop self-capacity as a way in which community empowerment is focused on power over their lives [3]. To realize community development systematically, planned manner to achieve better social, economic, and quality conditions of life. According to Jim Ife, [4],

Etymologically according to Nanih Machendrawati [5]. Development means empowering, strengthening, fostering, and prospering. In terms of terminology, the development of an Islamic community means a concerted and planned effort to prosper Muslims in all aspects of their lives according to the Koran and Sunnah's demands, whereas lexically, empowerment means strengthening. Technically, the term empowerment can be equated or at least equated with the term development; even these two terms, to some extent, are interchangeable or interchangeable.

According to Suharto 5 (five) empowerment programs, namely providing motivation, increasing awareness and capacity training, self-management, resource mobility, network development and development. Thus empowering farmers is very important to do because it 
touches the majority of Indonesia's population. And indirectly this will improve the economy of the Indonesian people, especially farmers. [6].

Sunyoto Usman in organizing and Community Development said that community empowerment is a process in the framework of strengthening what is commonly called community self-reliance or independence.

Empowerment is an effort or effort to further empower the "power" possessed by humans in the form of competency, authority and responsibility in order to improve performance in farming.[7]. Richard West [8] defines accommodation as the ability to adjust, modify, or regulate one's behavior in response to others.

In this case the development of empowerment activities carried out by providing support, motivation, increasing awareness and capacity training, self-management, resource mobility, network development and development. Thus community empowerment in the field of agribusiness can develop and be able to improve the economic welfare of the community and this is very important to do because it touches the majority of Indonesia's population who are farming communities. Albert and Hahnel, as quoted by Eddy Sugiarto [9], divide welfare theory into three parts, namely; Classical utilitarian, Neoclassical welfare theory, and New contraction approach. as Shil [10] in Piotr Sztompka's book asserts that: "Humans cannot live without tradition. although they often feel dissatisfied with their traditions."

Edi Suharto explained that community development in empowerment includes:

1. Empowerment is carried out to the community by means of training, and has objectives including developing individual community skills in carrying it out. The approach in this case focuses on task activities or micro approaches.

2. Community development in empowerment activities through the efforts made by groups in seeing and identifying problems that arise in the community and can be used as means or activities for community guidance or training carried out by groups to increase capacity and awareness, this approach is often called the approach. mezzo.

3. Development of empowerment activities in this approach model is a broader market system that leads to changes in the community environment and is directed towards social planning and social activities as a form of development in society, this approach is often referred to as a macro approach.[11].

\section{Research Method}

This type of research is classified as field research when viewed from the place where the research was conducted. Field research, namely research using information obtained from research objectives, hereinafter referred to as informants or respondents through data collection instruments such as questionnaires, interviews, observations and so on. Where the author will collect data by going directly to the field which is the object of research to study intensively about the various problems being studied in depth [13].

\section{Result and Discussion}

Empowerment is very important for the community and most of the poor are farmers, therefore empowerment is needed so that farmers can be independent and have potential that 
can be developed. Every society, has the potential that can be developed, meaning that no society is completely powerless so every society has the potential to progress if we want to develop it. Community development focuses on providing support, motivation, awareness raising and capacity training, self-management, resource mobility, network building and development.

Community development in the process of empowering agribusiness businesses in Pekalongan sub-district, East Lampung that is carried out in increasing the economic welfare of the community through agribusiness efforts is all types of activities or businesses that are carried out and programmed by farmer groups to their members, in the form of things that are carried out starting from identifying member problems to implementing empowerment. Empowerment used by the pekalonagan community: in community empowerment is 1) developing agribusiness technology and marketing in the digital era, 2) Forging strong partnerships with all group members and from this empowerment is able to increase community income results and reduce unemployment in adolescents at productive age.

\section{Conclusion}

Based on the results of the research that community empowerment is being carried out more focused on the development of agribusiness technology through a wider global market reach as well as strong cooperation among members, who have the same goal of improving the economic welfare of the community with the knowledge and skills to develop horticultural business effectively. and efficient in a more modern way.

Average daily income earned by farmers and horticultural plant sellers has also increased and varies greatly depending on the size of the capital used by members or the community in developing horticultural agribusiness enterprises in pekalongan, East Lampung.

Welfare in Pekalongan based on assets and income level is certainly in the welfare category by looking at the conditions of residence and business owned.

\section{References}

[1] James A.: Christenson \& Jerry W. Robinson, Jr Ames, Community Development In Perspective: (Lowa : State University Pres (2017)

[2] Suparjan, Hempri S.: Community Development from Development to Empowerment (Yogyakarta:Aditya Media (2013)

[3] Adi Fahrudin, Ph. D.: Empowerment, Participation and Strengthening Community Capacity (Bandung: Humaniora (2012)

[4] Albert and Hahnel.: Traditional Welfare Theory, See Eddy Sugiarto, Socio-Economic Welfare Theory, and Its Measurement, pp.263-269. Executive (2005)

[5] Journal: Volume IV, No II, (August 2007)Shils in Szompka, Sociology of Social Change, pp. 74. (Yogyakarta: Prenanda media group (2007)

[6] Arif Budimanta and Bambang Rudito.: Community Development Management Methods and Techniques, pp. 33. Jakarta: CSD (2008)

[7] Masdar Hilmy.: Initiating a Multiculturalism-Based Education Paradigm. Ulummuna Journal; Volume VII, Issue 12 Number 2 pp. 333 (July-December 2003)

[8] Piotr Sztompka.: Sociology of Social Change, pp.60-70.Jakarta: Prenada Media Group (2011) 
[9] Richard West and Lynn H. Turner.: Introduction to Communication Theory. pp.27. Jakarta: Salemba Humanika (2009)

[10] Abu Hurairah.: Community Organizing and Development Models and Strategy for CommunityBased Development,, (Bandung: Humaniora, 2012)

[12] Sukino, Sukino.: Building Agriculture with Empowerment of Farmers, (Yogyakarta: Pustak Baru Press, 2013)

[13] Abudin Nata, Islamic Studies Methodology (Jakarta: Raja Grafindo Persada, 2000) 